This is a self-archived - parallel published version of this article in the publication archive of the University of Vaasa. It might differ from the original.

\title{
Does state ownership of banks matter?
}

Author(s): Davydov, Denis

Title: $\quad$ Does state ownership of banks matter?

Year: $\quad 2018$

Version: Accepted manuscript

Copyright (C) 2018 Institute for Financial Management and Research, SAGE Publications.

Please cite the original version:

Davydov, D., (2018). Does state ownership of banks matter? Journal of Emerging Market Finance 17(2), 250-285. https://doi.org/10.1177/0972652718776862 


\title{
Does state ownership of banks matter? Russian evidence from the financial crisis.*
}

\author{
Denis Davydov ${ }^{* *}$
}

\begin{abstract}
This paper examines the effects of state ownership and government interventions on lending behavior and capitalization of banks over the period 2005-2011. Using data from the highly state-influenced Russian banking sector, it is documented that the relationship between state ownership and lending is nonlinear. While overall loan growth decreased and interest rates rose, it is found that fully state-controlled banks increased lending and charged lower interest rates during the crisis of 2008-2010. Moreover, fully state-owned and state-supported banks demonstrated counter-cyclical lending behavior during the crisis. However, while state-owned banks were better protected against asset default, there is a weak evidence to suggest that government interventions may result in increased riskiness of banks.
\end{abstract}

JEL classification: G01; G21; G28; G32; O16

Keywords: bank lending; state ownership; privatization; financial crisis; government interventions

* I am thankful to Sami Vähämaa, Andrei Vernikov, Stanley D. Smith, John Sedunov, Karolin Kirschenmann, Panu Kalmi, Zuzana Fungáčová, and participants at the BOFIT research workshop, the 5th Annual CInST Banking Workshop, the 2015 Southern Finance Association Conference, the 2015 Finnish Economic Association meetings and the 2014 Eastern Finance Association Conference for valuable comments on the previous versions of this paper. I also gratefully acknowledge the financial support from the Finnish Foundation for Economic Education.

${ }^{* *}$ D. Davydov is an Assistant Professor of Finance at the School of Accounting and Finance at the University of Vaasa. E-mail: denis.davydov@uva.fi; Tel: +358 (29) 449 8468; Postal address: P.O. Box 700, FI-65101 Vaasa, Finland. 


\section{Introduction}

It is generally accepted that state ownership of commercial banks is inefficient, may have a negative effect on financial performance, and is not superior to other forms of ownership (see e.g. La Porta et al., 2002; Barth et al., 2004; Bonin et al., 2005a; Boubakri et al., 2009; Cornett et al., 2010). Consequently, over the past few decades, governments of many developed countries have been rapidly transferring their ownership rights to the market and private investors. At the same time, many emerging countries that still have high levels of state ownership in banking sectors have been actively developing privatization programs (Megginson, 2005).

However, since 2008 and the onset of the global financial crisis, instead of massive privatization, both developed and emerging countries experienced large scale nationalization and bailouts of private banks (Brunnermeier, 2009; Erkens et al., 2012). Such actions were inevitable in most of the cases and were conducted in order to avoid large-scale bankruptcies and meltdowns of financial systems. ${ }^{1}$ This reverse transfer of ownership may indicate that state ownership of banks is not necessarily harmful and may even be more desirable in times of financial turmoil.

This paper focuses on the effects of government ownership on lending behavior and capitalization of commercial banks over the period 2005-2011. Using data from the highly concentrated and state-influenced Russian banking sector, it is documented that the relationship between state ownership and lending behavior is nonlinear. While overall banking sector experienced decline in lending with increased costs of debt, banks that were fully controlled by the government significantly increased lending amounts and charged lower interest rates during the crisis of 2008-2010. Furthermore, state-owned banks appeared to be more capitalized, and therefore, were better protected against asset default than privately owned banks. These empirical findings suggest that high levels of state ownership of banks may be particularly valuable during periods of financial turmoil.

The paper also examines the effects of government actions in response to the financial crisis of 2008-2010 on bank lending behavior and capitalization. To the best of the author's knowledge, this is the first attempt to assess the effectiveness of state interventions through the state-owned banks during the crisis period. The results indicate that government support of state-owned institutions seems to fulfill its aim and cause counter-cyclical behavior of supported banks.

Existing theories suggest that state ownership of commercial enterprises is ineffective because of at least three reasons. First, political interference always conflicts with market objectives, and therefore, would certainly deviate a firm from a value maximization aims (Shleifer and Vishny, 1994; Boycko et al., 1996). Second, managerial incentives in state-owned enterprises tend to be weaker compared to those in privately owned firms (Shleifer, 1998). Finally, inferior incentives of a government

\footnotetext{
${ }^{1}$ In the United Kingdom, for example, the British government had to step in and nationalize such banks as Northern Rock and Royal Bank of Scotland because of their inability to cope with financial difficulties caused by the financial crisis during 2008. In the U.S., Federal program of capital purchases accounted for more than 200 bill. USD that were spent on bailing out such banks as Citigroup, Wells Fargo and many others. These actions can be considered as partial (temporary) nationalization.
} 
as an owner to implement monitoring efforts may lead to sub-optimal levels of performance (Shirley and Walsh, 2000).

The prior empirical literature on state ownership of banks in general supports the theory and suggests that commercial banks with state ownership usually underperform those that are privately owned. A large number of studies primarily focus on the noncrisis periods and examine the association between state participation in the banking sector and either financial stability and development or bank performance itself. Many cross-sectional studies find a negative relationship between government ownership of banks and financial development, stability, and economic growth (Barth et al., 1999, 2004; La Porta et al., 2002; Gur, 2012). It is also well documented that government participation in the banking sector may affect lending behavior and be more politically connected (Sapienza, 2004; Dinc, 2005; Khwaja and Mian, 2005; Micco and Panizza, 2006; Micco et al., 2007; Carvalho, 2014; Infante and Piazza, 2014).

Another strand of literature suggests that state ownership of banks is also associated with lower performance, weaker corporate governance, and higher levels of risk. Cross-country studies find that state-owned banks are less efficient, experience lower profitability, have worse loan quality and higher interest expenses, lower governance quality, and tend to be more risky despite their lower average costs (Hawkins and Mihaljek, 2001; Mian, 2003; Bonin et al., 2005b; Iannotta et al., 2007; Borisova et al., 2012; Shen and Lin, 2012). Several country- or region-specific studies confirm these findings (see e.g. Berger et al., 2009; Cornett et al., 2010). More recently, it has been documented that state-owned banks tend to have higher levels of operating risk (which especially increases in election years) but much lower default risk compared to privately owned banks (Pennathur et al., 2012; Iannotta et al., 2013). However, Shen et al. (2014) argue that such underperformance of state-owned banks may be due to political aspects of the governmental role in the banking sector. This role requires state-owned banks to involve in acquisition of distressed banks. Furthermore, Shen et al. (2014) show that there are no differences in performance between state-owned banks that are not involved in mergers and acquisitions (or those that purchase nondistressed banks) and privately held banks.

Nevertheless, according to previous empirical evidence, bank efficiency and profitability as well as financial stability of the whole economy is less likely to be associated with state's participation in the banking sector as an owner. Ideally, as proposed by the theory, state ownership in the banking sector is desired to approach zero. However, since the majority of the empirical evidence comes from normal, noncrisis periods, the only conclusion we can make is that state ownership does not create any additional value during the stages of economic expansion. Yet, facing crises and economic downturns, governments are more likely to interfere and serve as a guarantee for distressed banking sector. ${ }^{2}$ Therefore, state ownership of banks may actually be particularly valuable in harsh times.

There are only a few studies that investigate the behavior of state-owned banks during crisis periods. One of these exceptions is Brei and Schclarek (2013), who show that government-owned banks in general increased lending during the financial crisis of

\footnotetext{
${ }^{2}$ Extensive literature review on the role of state ownership during the crisis is provided in the World Bank Global Financial Development Report (World Bank, 2012).
} 
2008-2010 by using a sample of 764 banks from 50 countries. They also find that typical state-owned banks do not receive more equity or deposits during the harsh times, and hence, the increase in lending is most likely to be associated with the government response to crisis situation. Another recent study by Cull and Martinez Peria (2013) examines the impact of bank ownership on credit growth in developing countries around the financial crisis of 2008-2010. They document that government ownership has different effects on lending growth in Eastern Europe and Latin America. In particular, state-owned banks significantly increased lending during the crisis compared to private and foreign banks in Latin America, while state ownership of banks in Eastern European countries did not impose notable lending growth during the credit crunch episode.

Furthermore, De Haas et al. (2012) argue that state-owned banks can be considered as a relatively stable source of credit compared to foreign bank subsidiaries (which were not part of the Vienna initiative) that are found to decrease their lending even before the financial crisis of 2008-2010 had started in a number of Eastern European countries. More recently, De Haas et al. (2015) find that state-owned banks reduced credit growth less in 2009. Finally, Fungáčová et al. (2013) document that credit supply levels varied across ownership types in Russia during the financial crisis of 2008-2010. Using stochastic frontier approach, they find that while overall credit supply diminished, the reduction was lower for state-owned banks and higher for foreign banks.

This paper contributes to the above literature by examining the direct effects of state ownership on lending behavior and bank capitalization, specifically around the time of the global financial crisis of 2008-2010 using a panel of Russian banks. A withincountry analysis that is less prone to endogeneity issues compared to large crosscountry studies is expected to provide a more detailed view on the effects of state ownership on bank lending behavior and capital buffer. In addition, the Russian banking sector, which can be characterized as highly state-influenced with dense concentration, provides an appropriate environment to examine this issue. The empirical analysis presented in this paper may also have important policy implications for the emerging markets with high state influence in the banking sector.

This paper is different from the discussed above literature in two aspects. First, according to several recent studies, the relationship between ownership structure and different aspects in bank operations may exhibit nonlinear behavior (see e.g. Barry et al., 2011; Iannotta et al., 2013). And given that none of these studies focus on potential non-linearity between state ownership and lending behavior and capitalization of banks, this paper contributes to the existing literature by examining the exact levels of state ownership in banks' equity. These data are manually collected from several sources that are discussed in more details in the data description section. Second, this paper aims to contribute to the existing literature on efficiency of government interventions in response to the financial crisis. Essentially, this is the first attempt to assess whether the government support through the state-owned banks has any effects on lending behavior and bank capitalization.

Using a sample of 348 large Russian banks, I find that the relationship between state ownership and lending behavior is nonlinear and high levels of state ownership may be more useful during financial crises. In particular, the results indicate that growth of 
loans is positively associated with high levels of government participation in the ownership stake of banks, especially during the crisis period. At the same time, fully state-owned banks charge lower interest rates on loans. Moreover, I find that state interventions during the crisis of 2008-2010 were rather successful as supported banks increased lending, while charging lower interest rates on their loans. It is also documented that there is a positive relationship between capital ratios and state ownership around the crisis, implying that government as an owner may provide more protection from asset default. However, there is a weak evidence to suggest that state intervention may have forced supported banks to take more risky projects, which negatively affected their capital ratios.

These results are broadly consistent with the existing studies that focus on the financial crisis period (see e.g. Brei and Schclarek, 2013; Fungáčová et al., 2013; Cull and Martinez Peria, 2013; De Haas et al., 2012, 2015). Although state ownership has a negative impact on bank performance, efficiency and economic development in normal times (see e.g. La Porta et al., 2002; Barth et al., 2004; Bonin et al., 2005a; Cornett et al., 2010), the empirical findings of this paper demonstrate that government participation in the banking sector may outweigh these disadvantages during crises episodes.

The remainder of this paper is organized as follows. Section 2 describes the Russian banking sector and discusses government participation in it. Section 3 introduces the data, while Section 4 presents the methodology. Empirical findings on the effects of government ownership of banks on lending behavior and capitalization as well as the effects of state interventions during the crisis are reported in Section 5. Finally, Section 6 concludes the paper and discusses potential policy implications.

\section{Overview of the Russian Banking Sector}

Although the number of commercial banks in Russia has been constantly decreasing over the last decade (from 1253 in 2005 to 978 in 2011), it is still relatively high if scaled to the size of the economy. For comparison, in the similar emerging market of Brazil there are less than 150 commercial banks. Hence, the Central Bank of Russia still follows the policy of decreasing the number of commercial banks by rising minimum capital requirements and imposing stricter financial standards. Minimum capital requirements, for example, doubled since 1997 from 5\% to 10\%. Nevertheless, even with such a large number of financial institutions, Russian banking sector is relatively concentrated both geographically and assets-wise. The top 200 banks account for more than $94 \%$ of total assets of the Russian banking sector, while the top 5 banks hold up to $50 \%$. Similar picture can be observed on the capital side - the top 200 banks hold 93\%, while the top 5 banks account for more than $50 \%$ of total capital. At the same time, Herfindahl-Hirschman Index (HHI) being at the moderate levels for assets (0.092) and capital (0.101) mainly due to the large number of financial institutions still remains relatively high for deposits $(0.225){ }^{3}$

\footnotetext{
${ }^{3}$ These numbers are as of end of 2011 according to the Central Bank of Russia.
} 
While high concentration can potentially cause lower levels of competition and lead to higher interest rates and fees, it may also lead to higher stability in the banking industry through better diversification, higher profitability and easiness of monitoring of large banks. In fact, it has been argued that high concentration is associated with higher interest margins only for foreign banks in Russia, while state-owned banks, despite their large market share, do not exploit their market power in terms of interest rates (Fungáčová and Poghosyan, 2011).

\section{(Table 1 here)}

Table 1 presents the main characteristics of the Russian banking sector. As can be noted from Panel A of the table, Russian banking sector experienced substantial growth over the last decade. Total assets as well as total capital grew by more than 4 times during 2005-2011. Commercial lending to non-financial firms and households also quadrupled over the same period. It can be also seen from the table that capital and commercial loans were growing proportionally to total assets of the banking sector. Hence, total capital to assets ratio remained approximately at the same level $12.5 \%$, while the ratio of commercial loans to total assets stayed at around $56 \%$.

Being moderately concentrated in terms of assets and capital, ownership density in the Russian banking sector is even more compact. Panel B of Table 1 characterizes ownership structure of the banking industry. As can be seen from the table, according the Central Bank of Russia (CBR) 50.2\% (50.8\%) of the industry's total assets (capital) were controlled by the state-governed banks by the end of 2011. It is important to note that there are no large differences in target markets between stateowned and privately held banks in Russia. Most of the banks apply the universal model of banking and follow the same regulations of the Central Bank of Russia, irrespective of their ownership structure. However, it is acknowledged that some of the state-owned banks may have politically related connections with their customers. These connections may potentially affect banks' lending behavior (Barry et al., 2016). ${ }^{4}$ Nevertheless, Berger et al. (2008) find only mixed support for the hypothesis that state-owned banks serve any particular kind of firms. It should also be noted that state ownership of commercial banks in Russia is customary. The largest three banks in Russia have always been state-owned. Hence, in contrast to most of the developed markets, the process of bailouts of banks in Russia during the financial crisis of 20082010 had only marginal effect on the distribution of state-controlled banking assets. In particular, the Russian government bailed out only a few relatively small regional banks in 2008-2010, while the reduction of systemic risk in the economy was achieved solely through the existing large state-owned commercial banks.

Although CBR defines a bank as state-owned if more than $50 \%$ of equity belongs to the government, certain influence on decision-making may be exerted even when government does not hold majority stake. Vernikov (2009), for example, finds that the difference between state-owned and state-controlled banks may significantly affect the determinants of market shares. He documents that the gap between state-owned and state-controlled (-influenced) banks is nearly 13\% of industry's total assets. Thus, the definition of state ownership must be treated with some caution. The CBR's

\footnotetext{
${ }^{4}$ Unfortunately, the data on exact borrowers of banks are not available, and hence cannot be controlled for in the empirical analysis.
} 
classification does not necessarily describe the overall influence of the government in the sector also because it does not consider a bank as a state-owned if state-owned industrial companies own the bank's equity.

Although foreign banks have doubled their market share since 2005, they still account only for about $17 \%(17.6 \%)$ of industry's total assets (capital). Nevertheless, it has been found that foreign banks tend to be more efficient than domestic private banks in Russia (Karas et al., 2010). Interestingly, it can be noted from Panel B of Table 1 that large private banks lost substantial amount of market share around the crisis. The total assets held by those banks decreased from $41.2 \%$ in 2005 to $27.5 \%$ in 2011 . Finally, it can be seen from the table that the number of other private banks decreased almost by one third - from 939 to 656 banks, while the market share held by these banks fell by roughly $4 \%$.

Apart from concentration of the banking sector, all commercial banks in Russia experienced significant difficulties during the financial crisis of 2008-2010. Formal indicators of the crisis first started to appear on the capital side of banks. Expecting and preparing for the possibility of bank runs, many financial institutions preferred to transfer their assets into more liquid instruments, which significantly distressed profitability and consequently negatively affected capital ratios. In addition, financial difficulties of borrowers forced many banks to increase their reserves and loan loss provisions. As a result, some banks ended up with negative capital. But in contrast to the Russian crisis of 1998, Russian banking sector managed to avoid massive bank runs and bankruptcies largely due to the extensive government support. While developed countries had to initiate exceptional monetary policies and force significant nationalization of financial institutions (Laeven and Valencia, 2010; Lenza et al., 2010), Russian government stepped in with capital injections, preferential loans on favorable terms, and long term deposits to state-owned banks. To a large extent, these actions allowed Russian banking sector to avoid a collapse.

\section{Data}

The empirical analysis in this paper is based on data on large Russian banks for fiscal years 2005-2011. The data are mainly obtained from Bureau Van Dijk's BankScope. Given the peculiarities of the Russian banking sector and its concentration, smaller banks that operate in specific fields or regions are not of great interest to this analysis. Therefore, all banks that had less than 100 mill. USD in total assets by the end of 2007 (the year prior to the crisis) are omitted from the sample. Further, banks with insufficient financial information are left out. Specialized credit institutions that mainly serve as development banks and governed by distinctive regulations are also excluded from the sample. ${ }^{5}$ Lastly, to avoid any potential bias, banks owned by foreign governments are not included in the analysis. In order to ensure that outliers do not affect the results, the data used in the analysis are winsorized at the $1 \%$ and $99 \%$ levels.

\footnotetext{
${ }^{5}$ For example, large state-owned 'Vnesheconombank' is excluded from the sample because of its specialized development activities and its exposure to special regulations that are set by the Federal Law "On the Bank for Development".
} 
The main variable of interest is state ownership. Many previous studies on state ownership of banks use a dummy variable that takes the value of one if government holds a certain percentage of equity (see e.g. Brei and Schclarek, 2013; Jackowicz et al., 2013; Shen and Lin, 2012; Iannotta et al., 2007). However, quite often the obtained dummies are rather static over time and account only for exceptional changes in ownership, depending on the definition of the variable. Moreover, dummy variables cannot capture nonlinear relationship, and therefore, may lead to incorrect inferences. In contrast to previous studies, this paper uses a different approach that accounts for possible dynamic changes in state ownership and for potential nonlinearity. Thus, instead of a dummy, this paper uses a continuous ownership variable defined as the percentage held by the government in bank's equity.

There are, however, two potential problems with this approach. First is the lack of historic data. For certain banks, usually smaller ones, BankScope does not contain all historical information on shareholders. If that was the case, the information on owners was hand-collected from different publicly available sources. ${ }^{6}$ The second problem arises from the complex ownership structures. As pointed out by Vernikov (2009), official classification of state ownership by the Central Bank of Russia is very narrow and congregates only on direct participation of federal or local government in more than $50 \%$ of equity stakes. In practice, governments may exert certain influence on bank's governance mechanisms even without holding controlling stakes. Moreover, governments may affect bank's behavior indirectly, through sophisticated pyramidtype ownership structures. Chernykh (2008), for instance, shows that Russian government exercises its control over some financial and industrial companies using extensive ownership pyramids. Therefore, to account for hidden state control, it is essential to determine the final ultimate owner. For this purpose, BankScope ownership data on financial institutions is augmented with Bureau van Dijk's Orbis database that also contains information on ultimate owners of industrial firms.

The ownership structure was manually ascertained up to the third level of major stakeholders. For example, if a bank's equity was mainly held by an industrial company that in turn was controlled by the federal or local government, this bank was defined as state-owned and the percentage of equity belonging to the government was calculated proportional to the stakes held in the industrial company. Fortunately, these pyramid ownership structures mostly prevail only in larger banks in Russia.

The final sample used in the empirical analysis consists of an unbalanced panel of 2,196 bank-year observations on 348 individual banks for the fiscal years 2005-2011. This paper does not consider data from the later periods because of the higher levels of political uncertainty and recent geopolitical conflicts. ${ }^{7}$ The number of observations varies across variables due to lack of financial data. The sample used covers about

\footnotetext{
${ }^{6}$ Mainly these sources are either the official web pages of banks or service of information disclosure operated by the Interfax media company that is available online at www.e-disclosure.ru.

${ }^{7}$ Presidential elections in Russia, for instance, took place in March 2012. This period can be characterized by increased political uncertainty, which may have had an impact on lending behavior of state-owned banks. It should be noted that elections of 2008 were less uncertain as ruling party was in favor. Moreover, the Ukrainian crisis of 2014 caused artificial constraints for the Russian financial sector as several countries imposed economic sanction on some of the state-owned and politically connected banks. These constraints may potentially affect the behavior of state-owned banks and therefore left out for further research.
} 
$90 \%$ of the country's banking assets and can thereby be considered representative of the whole Russian banking sector.

(Table 2 here)

Table 2 reports summary statistics of the sample. As can be noted, the sample is quite heterogeneous in term of bank size. Total assets vary from 2.12 to 336,534 million USD with mean of about 2.4 billion USD. Average growth rate of banks' total assets is fairly high - around 30\% per annum, while mean growth rate of loans is about $35 \%$. Russian bank also make an average reserve of $8.2 \%$ of gross loans to cover their potential losses, while equity covers about $16 \%$ of assets and $34 \%$ of net loans. Customers' deposits on average finance $56 \%$ of bank assets. The table also shows that the average Russian bank is rather profitable. While the mean of return on assets is only $1.44 \%$, average earnings before taxes to total assets are about $2 \%$. Average net interest revenue to assets is more than $5 \%$ and cost to income ratio of about $75 \%$ imply that Russian banks are relatively efficient and exert utility from attracting cheaper funds and maintaining low running costs.

\section{$4 \quad$ Methodology}

The empirical analysis begins with the examination of the relationship between bank ownership and growth of loans supply with the following regression specification:

$$
\begin{aligned}
\Delta L_{i, t}=\alpha_{0}+ & \beta_{1} G O V_{i, t}+\beta_{2} G_{O O V_{i, t}^{2}}+\beta_{3} S I Z E_{i, t-1}+\beta_{4} D E P_{i, t-1}+\beta_{5} P R O F_{i, t-1} \\
& +\beta_{6} I N C_{i, t-1}+\beta_{7} C T I_{i, t-1}+\beta_{8} C A P_{i, t-1}+\beta_{9} L L R_{i, t-1} \\
& +\sum_{k=1}^{n-1} \alpha_{k} B A N K_{i}^{k}+\sum_{t=2006}^{2011} \omega_{t} Y E A R_{i}^{t}+\varepsilon_{i, t}
\end{aligned}
$$

where $\Delta L_{i, t}$ is the growth rate of total loans by bank $i$ at time $t$. Following Micco and Panizza (2006) and Ferri et al. (2014), the growth rate of loans is defined as the difference between log-loans at time $t$ and log-loans at time $t-1$. GOV is the percentage of equity stake directly or indirectly held by the government and $G O V^{2}$ is a squared term of state ownership. Following recent literature on the ownership structure and banking (see e.g. Brei and Schclarek, 2013; Cull and Martinez Peria, 2013), control variables for bank size, sources of financing, profitability, income diversification, cost efficiency, capitalization, and riskiness are included. SIZE is the logarithm of total assets, while $D E P$ is the logarithm of deposits to assets ratio. $P R O F$ denotes profit before taxes scaled to total assets, INC is a proxy for income diversification calculated as net interest revenue divided by average assets, $C T I$ is the logarithm of cost to income ratio measured by operating costs divided by operating income, $C A P$ is the logarithm of capital ratio calculated as equity to assets ratio, $L L R$ is the logarithm of loan loss reserves to gross loans ratio. BANK and YEAR denote bank and year fixed effects. All the bank-specific control variables are lagged by one year. 
In addition to the above two-way fixed effects panel regression specification, further analysis uses a crisis dummy variable CRISIS that equals one in fiscal years 2008, 2009 , and 2010, and the interactions of $G O V$ and $G O V^{2}$ with the crisis dummy. This approach allows capturing the effect of state ownership on lending behavior relative to private banks during the crisis period.

Given relatively high concentration of the Russian banking sector and differences in funding sources, it is important to control for the geographical location of banks as well as for the easiness of access to external sources of financing. With this respect, two additional dummy variables are included in some specifications. Listed denotes whether a bank was listed on stock exchange during the sample period, while $\mathrm{H}$ quarters takes value of one if bank's headquarters were located in Moscow.

As the next step of the analysis, to examine the relationship between bank ownership and interest rates on loans, the following regression specification is estimated:

$$
\begin{aligned}
& A I R_{i, t}=\alpha_{0}+\beta_{1} G O V_{i, t}+\beta_{2} G O V_{i, t}^{2}+\beta_{3} S I Z E_{i, t}+\beta_{4} D E P_{i, t}+\beta_{5} P R O F_{i, t}+\beta_{6} I N C_{i, t} \\
& +\beta_{7} C_{T I} I_{i, t}+\beta_{8} C A P_{i, t}+\beta_{9} L L R_{i, t}+\beta_{10} G R O W T H_{i, t}+\beta_{11} A R D_{i, t} \\
& +\sum_{k=1}^{n-1} \alpha_{k} B A N K_{i}^{k}+\sum_{t=2006}^{2011} \omega_{t} Y E A R_{i}^{t}+\varepsilon_{i, t}
\end{aligned}
$$

where $A I R$ is the average interest rate on loans measured as interest income on loans divided by average gross loans. GOV, GOV ${ }^{2}$, SIZE, DEP, PROF, INC, CTI, CAP, $L L R, B A N K$, and YEAR are defined as in Equation (1). Besides these variables, two additional control variables are included in these regressions. According to the previous literature, cyclicality of financial sector may have an effect on economic conditions, including the level of interest rates on bank loans (see e.g. Cardarelli et al., 2011). Therefore, GROWTH - the growth rate of total assets is included to control for cyclicality of financial sector. It is measured as a percentage of the present to the previous year's total assets. To control for the relative levels of interest rates on the deposits market, $A R D$ - the average interest rate on deposits measured as interest expenses on customer deposits divided by average customer deposits is also included in these regressions. It is important to note that the bank-specific control variables are not lagged in these regression specifications. As described in Lainela and Ponomarenko (2012), high volatility of interest rates in Russia is customary and has been especially substantial in periods of markets stress. Given high volatility of interest rates in Russia, it is reasonable to use contemporaneous control variables since lagged values are less likely to capture associated effects on the current levels of interest rates.

Finally, the impact of state ownership on bank capitalization is examined with the following regression specification: 


$$
\begin{aligned}
& C_{A P}=\alpha_{0}+\beta_{1} G_{O V V_{i, t}}+\beta_{2} G_{O V}^{2}+\beta_{3} \operatorname{SIZE}_{i, t-1}+\beta_{4} D E P_{i, t-1}+\beta_{5} P_{R O F_{i, t-1}} \\
& +\beta_{6} I N C_{i, t-1}+\beta_{7} C T I_{i, t-1}+\beta_{8} L L R_{i, t-1}+\beta_{9} \text { GROWTH } H_{i, t-1} \\
& +\sum_{k=1}^{n-1} \alpha_{k} B A N K_{i}^{k}+\sum_{t=2006}^{2011} \omega_{t} Y E A R_{i}^{t}+\varepsilon_{i, t}
\end{aligned}
$$

where $C A P$ is the logarithm of capital ratio of bank $i$ at time $t$, measured by total equity divided by total assets. GOV, GOV ${ }^{2}$, SIZE, DEP, PROF, INC, CTI, LLR, GROWTH, BANK, and YEAR are defined as in Equations (1) and (2). All control variables in this regression specification are one year lagged.

\section{$5 \quad$ Empirical Results}

\subsection{Univariate tests}

Table 3 reports the comparison of the main variables between state-owned and privately owned banks. As can be noted from Panel A of the table, average growth rate of loans seems to be on the same level for state- and privately owned banks during the whole sample period 2005-2011. Loan portfolios of these banks were growing on average by $35 \%$ per annum. Average capital ratio measured by the equity to total assets ratio is about $16 \%$ for all ownership types and the difference between them is not statistically significant. However, as can be noted from the table, there is highly statistically significant difference in average interest rates on loans between banks. State-owned banks charged on average about $13 \%$ on their commercial loans, while private banks were charging 134 basis points higher interest rates on their loans.

(Table 3 here)

Next, the means of the same variables are compared exclusively during the crisis period - 2008-2010. Panel B of Table 3 reports comparison of means and medians of lending behavior and bank capitalization variables between state-owned and privately owned banks year by year. As can be noted, growth rates of loans are significantly lower in periods of markets stress for both types of commercial banks. The average growth rate of loans for state-owned banks varies between roughly $8 \%$ and $11.5 \%$, while the corresponding number for private banks is much more volatile and varies from $-4.9 \%$ to $24.3 \%$. However, statistical significant difference between two types of banks can be observed only in 2008 in median and in 2009 in mean loans growth rate. Median privately owned bank shrank its lending by more than $4.5 \%$ in the beginning of the crisis, while the credit portfolio of median state-owned bank grew by more than $7 \%$ in 2008 . This difference is significant at the $10 \%$ level. Moreover, in the peak year of the crisis, in 2009, the average credit portfolio of state-owned bank experienced faster growth than in 2008 and rose up to $11.5 \%$, while lending by privately owned banks continued shrinking and decreased by $4.9 \%$. This difference is statistically significant at the 5\% level. Nevertheless, in 2010 both types of banks experienced growth in lending but the difference is not statistically significant. 
As can be seen from the table, average capital ratios of private and state-owned banks were increasing in 2008 and 2009 but slightly decreased in 2010 for state-owned banks, while private banks experienced a decline of about $1.3 \%$ from the previous year. However, the difference between two samples is not statistically significant in any of the years. At the same time, the difference in interest rates on loans is consistently significant at the $1 \%$ and $5 \%$ levels throughout the whole crisis period. Thus, in 2008 state-owned banks charged 167 basis points lower interest than their private rivals. However, average interest rates on loans slightly increased in 2009 but state-owned banks still were charging 149 basis points lower interest rate. Furthermore, interest rates decreased to pre-crisis levels in 2010, while the interest rate spread between state-owned and privately owned banks increased even more. Government-owned banks charged 211 basis points lower interest rate on their loans than privately owned banks. Overall, Panel B of Table 3 indicates that there are significant differences in lending behavior between state-owned and private banks during the crisis period.

\subsection{State ownership and bank lending behavior}

Table 4 presents the estimation results of Equation (1) with the growth of total loans as the dependent variable. Models 1-3 are estimated for the whole sample period 2005-2011, while Models 4-5 specifically examine the crisis period 2008-2010. Model 1 includes dummy variables for banks that are listed and located in the capital city but excludes bank fixed effects, whereas Model 2 is a two-way fixed effects regression. Model 3, in turn, includes a dummy variable that proxies for the crisis period that equals one in fiscal years of 2008, 2009, and 2010. In addition, interactions of the state ownership and squared state ownership with the crisis dummies are included into the model. Model 4 is estimated in a similar manner as Model 2 but for the crisis period only, whereas Model 5 uses variable (GOV-High) with high levels of state ownership (at least $95 \%$ of equity) for robustness check of nonlinear relationship between growth of loans and state ownership of banks. As can be noted from the table, all models have a good explanatory power with adjusted Rsquares varying between $25 \%$ and $42 \%$.

\section{(Table 4 here)}

First four models in Table 4 suggest that state ownership is negatively related to the loan growth rates. However, higher levels of state participation in banks' equity has a reverse effect and render statistically significant positive effect on growth rates of loans, implying that the relationship between state ownership and lending growth is nonlinear. The observed non-linearity in state ownership and loan growth is illustrated in Figure 1A, which plots the annual loan growth rates for different levels of state stakes in banks' equity during the crisis of 2008-2010. As can be seen from the figure, the loan growth was around zero for an average bank where the government held up to $50 \%$ of equity. But those banks where the government kept greater equity stakes were able to sustain higher loan growth rates. The average growth rate of loans for fully state-owned banks during the crisis was about $20 \%$ per annum.

(Figure 1 (A and $\mathrm{B})$ here) 
Model 3 in Table 4, in turn, implies that the crisis of 2008-2010 had a significant negative effect on loans growth. However, the interaction of state ownership and the crisis dummy, Crisis $\times G O V$, is positive and significant at the $10 \%$ level. Unreported F-test indicates that the hypothesis that the sum of the coefficients on GOV and Crisis $\times G O V$ is equal to zero cannot be rejected, suggesting that general negative effect of state ownership on loan growth may have been canceled out during the crisis period. Magnitudes of these estimates suggest that state-owned banks decreased their lending by less than did private banks in 2008-2010.

Yet, the estimates of Model 5 suggest that banks that were fully owned by the government had a positive impact on loans growth particularly during the crisis period. The magnitude of the estimated coefficients indicates that loans on average grew by one and a half percentage points faster in fully state-owned banks during the episode of financial stress. This argument is further supported in Figure 1B, which plots mean loans growth rates for different ownership types through the whole sample period. As can be seen from the figure, the average growth rate of loans significantly decreased in 2008. However, while the growth rates of loans remained close to zero for private banks and state-owned banks maintained rather nominal growth of about $10 \%$, fully state-owned banks, in turn, substantially increased lending by almost $60 \%$ in 2009. Moreover, as loans growth rates began to recover in 2010 , fully state-owned banks decreased lending to the market averages. This correlation indicates that fully state-owned banks may actually act counter-cyclically during the crisis episodes as the result of government response to market stresses.

The estimated coefficients of Model 5 in Table 4 also suggest that smaller, less efficient but more profitable banks with larger deposits base and diverse income structure are positively associated with loan growth rates. Interestingly, Models 4 and 5 suggest that capital ratios of banks matter for the growth rate of loans only during the crisis period. This result is consistent with the prior evidence from the developed markets that suggests that the relationship between capital ratios and bank lending is significant only during the financial crisis (see e.g. Carlson et al., 2013).

Next, the relationship between state ownership of banks and average interest rates charged on loans is examined. The estimation results of Equation (2) with the interest income on loans to average gross loans ratio as the dependent variable are reported in Table 5. Models are specified in a similar manner as in Table 4.

\section{(Table 5 here)}

The estimates of Model 1 in Table 5 suggest that average interest rates on loans are negatively associated with the state ownership. Yet, the model also indicates that this relationship may be nonlinear. The estimated coefficients for $G O V$ and $G O V^{2}$ are not statistically significant in Models 2 and 3. Furthermore, Model 3 provides strong evidence to suggest that average interest rates on loans increased by more than 1.3 percentage points during the crisis period. However, state-owned banks increased rates by less than the private banks. Figure $2 \mathrm{~A}$ plots the relationship between state participation in bank's equity and average interest rates on loans during the crisis of 2008-2010. The Figure shows that the difference in interest charged on loans is about $1.25 \%$ between partly and fully state-owned banks. While partly state-owned banks 
charged, on average, about $13.25 \%$, fully state-owned bank required about $12 \%$ on their loans during the crisis period.

(Figure 2 (A and B) here)

Model 4 in Table 5 confirms these findings and implies that fully state-owned banks charged lower interest rates on their loans during the financial crisis of $2008-2010$ as the estimated coefficient for $G O V^{2}$ is negative and statistically significant at the $1 \%$ level. Model 5 supports these findings as the estimated coefficient for $\mathrm{GOV}$-High is negative and significant, implying that conditional average interest rate on loans for fully state-owned banks is six percentage points lower, assuming that bank-specific control variables are fixed. Figure $2 \mathrm{~B}$ illustrates mean interest rates on loans across ownership types. As can be seen from the figure, private banks started to increase their interest rates on loans already in 2007 as the response to an average increase in volatility on the global financial markets. As the result, the interest rate on loans by these banks rose from about $14 \%$ in 2007 to almost $16 \%$ in 2009. State-owned banks, in turn, had lower volatility in interest rates than private banks during the crisis but also marginally increased in 2009 . What is more remarkable is that fully state-owned banks were consistently decreasing their interest rates on loans even amidst the financial crisis of 2008-2010. Hence, this evidence suggests a counter-cyclical behavior of fully state-owned banks not only in lending amounts but also in relative costs of loans.

As for the control variables in Table 5, as one would expect, with the change in market rates, average rates on loans and rates on deposits are positively related across all models. Similarly, net interest revenue to average assets ratio is positively associated with interest rates on loans. In the full sample period estimations interest income on loans to average gross loans ratio is negatively associated with the capital ratio, while this significance is, however, vanished in the crisis period. Finally, positive relationship between interest rates on loans and loan loss reserves to gross loans ratio is observed in most of the models, implying that banks charge higher interest rates if the quality of their loan portfolio is worsening. All models have very good explanatory power with R-squares varying between $29 \%$ and $71 \%$.

\subsection{State ownership and bank capitalization}

As the next step of the analysis, the association between state ownership and bank capitalization is examined. Table 6 presents estimation results of Equation (3). The dependent variable now is the logarithm of capital ratio, measured as total equity divided by total assets.

Similarly to Tables 4 and 5, Model 1 in Table 6 uses two additional dummy variables, Listed and H-quarters that capture whether a bank is listed on a stock exchange and whether the headquarters of the bank is located in the capital city. The estimated coefficient for Listed is negative and statistically significant at the $10 \%$ level, implying that publicly listed banks may be more risky than non-listed banks in terms of bank's capital. In contrast, the estimated coefficient for H-quarters is positive and highly statistically significant, suggesting that banks located in Moscow are better capitalized. The model also shows that the squared term of state ownership is 
positively related to the capital ratio. However, Models 2, 3 and 4, which also include bank fixed effects, do not support this relationship and indicate that capital ratios are not associated with state ownership of banks. These results also do not provide strong evidence on nonlinear relationship between state ownership and bank capital ratios.

Consistent with the univariate tests in Table 3, Model 3 in Table 6 shows that average capital ratio increased during the financial crisis of 2008-2010 as the estimated coefficient for Crisis is positive and statistically highly significant. Given that the relationship between state ownership and bank capitalization appears to be linear, Model 5 estimates Equation (3) using a dummy variable that take the value of one if the government held more than $20 \%$ of a bank's equity. The estimates of this specification indicate that state-owned banks, on average, were better capitalized during the crisis period, as the coefficient for the dummy variable is positive and statistically significant at the $5 \%$ level. The explanatory power of this model is very high - 83\%, while in Models 1-4, the R-squares vary between $23 \%$ and $83 \%$.

\section{(Table 6 here)}

Regarding the control variables, SIZE, CTI and GROWTH seem to be negatively related to the capital ratio, while profitability and loan loss reserve to gross loans ratio seem to have positive effect on banks' capitalization. The coefficients for these variables are statistically significant at the conventional levels in most of the specifications. Finally, being negatively related to the capital ratio in the whole sample period (as suggested by Model 1), deposits to assets ratio seems to switch its relationship to positive during the crisis period.

\subsection{The effect of state intervention during the financial crisis}

During the recent financial crisis state interventions into the banking sector have increased around the world. States with low levels of state ownership of commercial banks had to nationalize or bailout not only large systemic banks but also smaller ones in order to avoid the collapse of the financial system. Countries with substantial state influence in the banking sector, in contrast, used their ownership stakes in banks for liquidity injections and recapitalization. While the evidence on contribution of bailout programs like Troubled Asset Relief Program (TARP) is rather mixed and does not provide a definitive conclusion (see e.g. Bayazitova and Shivdasani, 2012; Black and Hazelwood, 2013; Harris et al., 2014; Veronesi and Zingales, 2010), the effects of government intervention through the state-owned banks remains unknown. This section aims to fill this gap by examining the effect of state support on lending behavior and bank capitalization in the highly government-influenced Russian banking sector.

During the financial crisis of 2008-2010 besides other quantitative easing, Russian government provided additional liquidity to the banking sector through preferential subordinated loans. It allocated about 700 bill. RUB (about 25 bill. USD) to 18 commercial banks and roughly $93 \%$ of this sum went to state-owned institutions. Hence, it is reasonable to assume that government response to the crisis in the banking sector has been mainly realized through the state-owned financial 
institutions. Table 7 presents estimation results of the effects of state intervention on bank lending behavior and capitalization.

(Table 7 here)

Using a dummy variable $G O V-S U P$ as the main explanatory variable which takes the value of 1 if a bank received monetary support from the government during the crisis episode, Models 1-3 of Table 7 re-estimate Equations 1-3 for the sub-sample period of 2008-2011. In Model 1, state support had a significant positive effect on loans growth rates. Financial institution that received such support increased lending by about $13 \%$. Model 2, in turn, indicates that these banks also charged significantly lower interest rates on their loans. The estimated coefficient suggests that banks, which received state support, decreased their interest rates on loans by 1.4 percentage points.

Interestingly, the results of Model 3 in Table 7 suggest that supported by the government banks had roughly 7\% lower capital ratio. Given that capital ratio may be used as the proxy for bank risk-taking, these results indicate that state-supported banks were enforced to involve in riskier operations during and right after the crisis period. Assuming that government response to the crisis is rather counter-cyclical, increased lending is most likely to be associated with riskier strategies that affect the level of reserves and consequently the capital ratio. Although the estimated coefficient is only marginally significant at the $10 \%$ level, these results are broadly consistent with the recent evidence on state ownership of banks and risk-taking (Angkinand and Wihlborg, 2010; Dong et al., 2014). Political and social aspects of state support of financial institution may force state-controlled banks to take more risk in order to serve as a counter-cyclical tool in harsh times.

\subsection{Robustness checks}

To ensure robustness of the results, several additional tests are performed. ${ }^{8}$ First, main specifications of Equations 1,2 and 3 are re-estimated using a dummy variable instead of ownership percentages. Given that governments may exert certain influence on bank's governance mechanisms even without holding controlling stakes this variable takes the value of one if the government holds more than $20 \%$ of the bank's equity. Similar tests are also performed using a 50\% ownership definition. To account for non-linearity in Equations 1 and 2, this dummy variable was split into two variables for high and low levels of state influence. Specifically, high level of state influence is defined if the government holds at least $95 \%$ of equity, while low level is defined if less than $50 \%$ belongs to the government. All results with dummy variables confirm main conclusions of the paper.

Second, possible differences between private foreign and domestic banks may drive some of the estimated coefficients for state-owned banks. Therefore, additional variable for foreign ownership of banks is included in all regression specifications of all models. Similarly to state ownership variable, foreign ownership is varying from $20 \%$ to $100 \%$. Conclusions made in this paper remain unchanged after accounting for the foreign ownership of banks.

\footnotetext{
${ }^{8}$ These tests are unreported for the sake of brevity but available from the author upon request.
} 
Finally, exchange listed banks may potentially have better access to funds which may affect the results. Hence, in addition to the analysis with the dummy variable Listed, which takes the value of one if bank was listed on a stock exchange, Equations 1-3 are re-estimated in the two sub-samples of privately owned and publicly traded banks. There are 54 banks that were listed on stock exchanges during the sample period. The results of these tests indicate that the observed relationship between state ownership and lending behavior and capitalization holds for both privately held and publicly traded banks.

\section{Conclusions and Policy Implications}

While the issue of privatization of state-owned financial institutions is an ongoing concern in many emerging markets, the global financial crisis of 2008-2010 reemphasized the importance of government support of the financial sector in both developed and emerging countries. This paper examines the association between different levels of state ownership and lending behavior and capitalization of commercial banks. In particular, using data on 348 large banks from the highly concentrated and state-influenced Russian banking sector over the period 2005-2011, the paper investigates whether government ownership of banks has any implications for loan growth rates, interest rates charged on loans, and capital ratios.

The empirical findings reported in this paper contribute to the existing literature that focuses on the association of state ownership and lending behavior of banks around the crisis episodes (see e.g. Bertay et al., 2015; Brei and Schclarek, 2013, 2015; Cull and Martinez Peria, 2013; Fungáčová et al., 2013) by documenting non-linearity in the relationship between state ownership and lending behavior of banks. In addition, this paper is the first to analyze the effect of state intervention through state-owned banks on bank lending behavior and capitalization. While commercial lending decreased and average interest rates rose during the crisis of 2008-2010, it is found that state-owned banks decreased lending and increased interest rates by less than private banks. Moreover, the results show that fully state-owned banks, in fact, enhanced lending and charged lower interest rates. These findings indicate that fully state-owned banks may serve as a counter-cyclical power during the crisis episodes. Furthermore, state-owned banks were better protected against asset default by having higher capital ratios during the crisis. However, there is a weak evidence to suggest that state intervention forced supported banks to engage in riskier lending which negatively affected their capital ratios. Nevertheless, government support of stateowned banks seemed to fulfill its aim and caused an increase in lending, while drove the interest rates on loans downwards despite increased riskiness during the crisis. These findings, in turn, provide further evidence on the importance of state ownership of banks during periods of markets stress.

The observed large-scale nationalization of banks in many countries during the global financial crisis brought the argument of a negative effect of state ownership of banks to a substantial controversy. The results of this paper lead to policy implications, which may be especially relevant in times of markets stress. First, they suggest that state-owned banks may serve as a stabilizing and counter-cyclical power on the 
commercial loans market. Instead of mass bailouts of private banks in times of crisis, governments may exploit their participation in equity stakes and make direct liquidity injections through capital increases and preferential loans. Such actions, if implemented properly, may lead to general stabilization of the banking sector as a whole.

Second, during crises uninsured depositors are more likely to run rather than monitor or verify leaked negative information on commercial banks. Even with the sufficient deposit insurance system, privately owned banks are more susceptible to bank runs amidst financial turmoil. Recent example of the Northern Rock - a British bank that suffered a severe bank run and was fully nationalized during the crisis of 2008-2010 supports this statement. In contrast, as a bank's shareholder, government may act as an additional guarantee to depositors and thus prevent them from a funds withdrawal.

Third, the existing evidence on benefits of bank dependence during the crisis periods and superiority of bank debt to other sources of corporate debt for industrial firms (see e.g. Allen and Paligorova, 2015; Davydov and Vähämaa, 2013) implies that state ownership of banks may have important implications for the real sector as well. If governments are acting as a balancing source of credit in crises times, firms that have relationships with state-owned banks would potentially have better options for refinancing and renegotiations in case of financial distress.

Finally, several recent studies provide empirical evidence to suggest that privatization of state-owned banks may in fact have harmful effects on financial stability and development and argue that governments should not hurry to privatize their financial sectors (see e.g. Andrianova et al., 2008; Andrianova, 2012; Karas et al., 2010; Körner and Schnabel, 2011). On the contrary, state ownership of banks may be associated with higher long-run economic growth rates (Andrianova et al., 2012). The empirical findings of this paper suggest that state ownership of banks may be particularly valuable in periods of financial turmoil, when governments exert their interventions through state-controlled banks and provide stability to the whole financial system. 


\section{References}

Allen, J. and T. Paligorova (2015). Bank loans for private and public firms in a liquidity crunch. Journal of Financial Stability 18, 106-116.

Andrianova, S. (2012). Public banks and financial stability. Economics Letters 116(1), 86-88.

Andrianova, S., P. Demetriades, and A. Shortland (2008). Government ownership of banks, institutions, and financial development. Journal of Development Economics 85(1-2), 218-252.

Andrianova, S., P. Demetriades, and A. Shortland (2012). Government ownership of banks, institutions, and economic growth. Economica 79(315), 449-469.

Angkinand, A. and C. Wihlborg (2010). Deposit insurance coverage, ownership, and banks' risk-taking in emerging markets. Journal of International Money and Finance 29(2), 252-274.

Barry, T., L. Lepetit, and F. Strobel (2016). Bank ownership structure, lending corruption and the regulatory environment. Journal of Comparative Economics 44(3), 732-751.

Barry, T., L. Lepetit, and A. Tarazi (2011). Ownership structure and risk in publicly held and privately owned banks. Journal of Banking and Finance 35(5), 13271340 .

Barth, J., G. Caprio, and R. Levine (1999). Banking systems around the globe: Do regulation and ownership affect performance and stability? World Bank Policy Research working paper, 2325.

Barth, J., G. Caprio, and R. Levine (2004). Bank regulation and supervision: What works best? Journal of Financial Intermediation 13(2), 205-248.

Bayazitova, D. and A. Shivdasani (2012). Assessing TARP. Review of Financial Studies 25(2), 377-407.

Berger, A., I. Hasan, and M. Zhou (2009). Bank ownership and efficiency in China: What will happen in the world's largest nation? Journal of Banking and Finance 33(1), 113-130.

Berger, A., L. Klapper, M. Martinez Peria, and R. Zaidi (2008). Bank ownership type and banking relationships. Journal of Financial Intermediation 17(1), 37-62.

Bertay, A., A. Demirgüç -Kunt, and H. Huizinga (2015). Bank ownership and credit over the business cycle: Is lending by state banks less procyclical? Journal of Banking and Finance 50, 326-339.

Black, L. and L. Hazelwood (2013). The effect of TARP on bank risk-taking. Journal of Financial Stability 9(4), 790-803. 
Bonin, J., I. Hasan, and P. Wachtel (2005a). Bank performance, efficiency and ownership in transition countries. Journal of Banking and Finance 29(1), 3153.

Bonin, J., I. Hasan, and P. Wachtel (2005b). Privatization matters: Bank efficiency in transition countries. Journal of Banking and Finance 29(8-9), 2155-2178.

Borisova, G., P. Brockman, J. Salas, and A. Zagorchev (2012). Government ownership and corporate governance: Evidence from the EU. Journal of Banking and Finance 36(11), 2917-2934.

Boubakri, N., J.-C. Cosset, and O. Guedhami (2009). From state to private ownership: Issues from strategic industries. Journal of Banking and Finance 33(2), 367379.

Boycko, M., A. Shleifer, and R. Vishny (1996). A theory of privatization. Economic Journal 106(435), 309-319.

Brei, M. and A. Schclarek (2013). Public bank lending in times of crisis. Journal of Financial Stability 9(4), 820-830.

Brei, M. and A. Schclarek (2015). A theoretical model of bank lending: Does ownership matter in times of crisis? Journal of Banking and Finance 50, 298307.

Brunnermeier, M. (2009). Deciphering the liquidity and credit crunch 2007-2008. Journal of Economic Perspectives 23(1), 77-100.

Cardarelli, R., S. Elekdag, and S. Lall (2011). Financial stress and economic contractions. Journal of Financial Stability 7(2), 78-97.

Carlson, M., H. Shan, and M. Warusawitharanaa (2013). Capital ratios and bank lending: A matched bank approach. Journal of Financial Intermediation 22(4), 663-687.

Carvalho, D. (2014). The real effects of government-owned banks: Evidence from an emerging market. Journal of Finance 69(2), 577-609.

Chernykh, L. (2008). Ultimate ownership and control in Russia. Journal of Financial Economics 88(1), 169-192.

Cornett, M., L. Guo, S. Khaksari, and H. Tehranian (2010). The impact of state ownership on performance differences in privately-owned versus state-owned banks: An international comparison. Journal of Financial Intermediation 19(1), 74-94.

Cull, R. and M. Martinez Peria (2013). Bank ownership and lending patterns during the 2008-2009 financial crisis: Evidence from Latin America and Eastern Europe. Journal of Banking and Finance 37(12), 4861-4878. 
Davydov, D. and S. Vähämaa (2013). Debt source choices and stock market performance of Russian firms during the financial crisis. Emerging Markets Review 15, 148-159.

De Haas, R., Y. Korniyenko, E. Loukoianova, and A. Pivovarsky (2012). Foreign banks and the Vienna initiative: Turning sinners into saints. European Bank for Reconstruction and Development (EBRD) working paper, 143.

De Haas, R., Y. Korniyenko, A. Pivovarsky, and T. Tsankova (2015). Taming the herd? Foreign banks, Vienna initiative and crisis transmission. Journal of Financial Intermediation 24(3), 325-355.

Dinc, I. (2005). Politicians and banks: Political influences on government-owned banks in emerging markets. Journal of Financial Economics 77(2), 453-479.

Dong, Y., C. Meng, M. Firth, and W. Hou (2014). Ownership structure and risktaking: Comparative evidence from private and state-controlled banks in China. International Review of Financial Analysis 36, 120-130.

Erkens, D., M. Hung, and P. Matos (2012). Corporate governance in the 2007-2008 financial crisis: Evidence from financial institutions worldwide. Journal of Corporate Finance 18(2), 389-411.

Ferri, G., P. Kalmi, and E. Kerola (2014). Does bank ownership affect lending behavior? Evidence from the Euro area. Journal of Banking and Finance 48, 194-209.

Fungáčová, Z., R. Herrala, and L. Weill (2013). The influence of bank ownership on credit supply: Evidence from the recent financial crisis. Emerging Markets Review 15, 136-147.

Fungáčová, Z. and T. Poghosyan (2011). Determinants of bank interest margins in Russia: Does bank ownership matter? Economic Systems 35(4), 481-495.

Gur, N. (2012). Government ownership of banks, job creation opportunities and employment growth. Economics Letters 117(2), 509-512.

Harris, O., D. Huerta, and T. Ngo (2014). The impact of TARP on bank efficiency. Journal of International Financial Markets, Institutions and Money 24, 85104.

Hawkins, J. and D. Mihaljek (2001). The banking industry in the emerging market economics: Competition, consolidation and systemic stability: An overview. Bank for International Settlements (BIS) working paper, 4, 1-44.

Iannotta, G., G. Nocera, and A. Sironi (2007). Ownership structure, risk and performance in the European banking industry. Journal of Banking and Finance 31(7), 2127-2149. 
Iannotta, G., G. Nocera, and A. Sironi (2013). The impact of government ownership on bank risk. Journal of Financial Intermediation 22(2), 152-176.

Infante, L. and M. Piazza (2014). Political connections and preferential lending at local level: Some evidence from the Italian credit market. Journal of Corporate Finance 29, 246-262.

Jackowicz, K., O. Kowalewski, and L. Kozlowski (2013). The influence of political factors on commercial banks in Central European countries. Journal of Financial Stability 9(4), 759-777.

Karas, A., K. Schoors, and L. Weill (2010). Are private banks more efficient than public banks? Evidence from Russia. Economics of Transition 18(1), 209-244.

Khwaja, A. and A. Mian (2005). Do lenders favor politically connected firms? Rent provision in an emerging financial market. Quarterly Journal of Economics 120(4), 1371-1411.

Körner, T. and I. Schnabel (2011). Public ownership of banks and economic growth. The impact of country heterogeneity. Economics of Transition 19(3), 407-441.

La Porta, R., F. Lopez-de Silanes, and A. Shleifer (2002). Government ownership of banks. Journal of Finance 57(1), 265-301.

Laeven, L. and F. Valencia (2010). Resolution of banking crises: The good, the bad, and the ugly. $I M F$ working paper (10/146).

Lainela, S. and A. Ponomarenko (2012). Russian financial markets and monetary policy instruments. Bank of Finland Institute for Economies in Transition (BOFIT) discussion paper (3/2012).

Lenza, M., H. Pill, and L. Reichlin (2010). Monetary policy in exceptional times. Economic Policy 25(62), 295-339.

Megginson, W. (2005). The economics of bank privatization. Journal of Banking and Finance 29(8), 1931-1980.

Mian, A. (2003). Foreign, private domestic, and government banks: New evidence from emerging markets. University of Chicago working paper.

Micco, A. and U. Panizza (2006). Bank ownership and lending behavior. Economics Letters 93(2), 248-254.

Micco, A., U. Panizza, and M. Yanez (2007). Bank ownership and performance. Does politics matter? Journal of Banking and Finance 31(1), 219-241.

Pennathur, A., V. Subrahmanyam, and S. Vishwasrao (2012). Income diversification and risk: Does ownership matter? An empirical examination of Indian banks. Journal of Banking and Finance 36(8), 2203-2215. 
Sapienza, P. (2004). The effects of government ownership on bank lending. Journal of Financial Economics 72(2), 357-384.

Shen, C., I. Hasan, and C. Lin (2014). The governments' role in government-owned banks. Journal of Financial Services Research 45(3), 307-340.

Shen, C. and C. Lin (2012). Why government banks underperform: A political interference view. Journal of Financial Intermediation 21(2), 181-202.

Shirley, M. and P. Walsh (2000). Public versus private ownership: The current state of debate. World Bank Policy Research working paper, 2420.

Shleifer, A. (1998). State versus private ownership. Journal of Economic Perspectives 12(4), 133-150.

Shleifer, A. and R. Vishny (1994). Politicians and firms. Quarterly Journal of Economics 109(4), 995-1025.

Vernikov, A. (2009). Russian banking: The state makes a comeback? Bank of Finland Institute for Economies in Transition (BOFIT) discussion paper (24/09).

Veronesi, P. and L. Zingales (2010). Paulson's gift. Journal of Financial Economics 97(3), 339-368.

World Bank (2012). Global financial development report 2013: Rethinking the role of the state in finance. World Bank. 
Table 1. Main characteristics of the Russian banking sector.

The table reports an overview of the Russian banking industry. Panel A describes the main financial characteristics of the Russian banking sector, while Panel B portrays the ownership structure of the industry. The data are obtained from the Central Bank of Russia reports.

\begin{tabular}{lrrrr}
\hline Panel A. Russian banking sector & 2005 & 2011 & Change, USD & Change, \% \\
\hline Total assets, in bill. USD & 341.3 & 1415.3 & +1074.0 & +414.7 \\
Total capital, in bill. USD & 43.5 & 178.2 & +134.7 & +409.7 \\
- \% to total assets & 12.74 & 12.59 & & -0.15 \\
Total loans to non-financial firms and & & & & \\
households, in bill. USD & 190.9 & 791.1 & +600.2 & +414.4 \\
- \% to total assets & 55.94 & 55.89 & & -0.05 \\
Capital adequacy, \%* & 16.0 & 14.7 & & -1.30
\end{tabular}

\begin{tabular}{lrrr|rrr}
\hline Panel B. Ownership structure & \multicolumn{2}{c}{2005} & \multicolumn{2}{c}{2011} \\
& Number & $\begin{array}{r}\text { \% of total } \\
\text { assets }\end{array}$ & $\begin{array}{r}\text { \% of total } \\
\text { capital }\end{array}$ & $\begin{array}{r}\text { \% of total } \\
\text { assets }\end{array}$ & $\begin{array}{r}\text { \% of total } \\
\text { capital }\end{array}$ \\
State owned banks ** & 32 & 40.7 & 33.8 & 26 & 50.2 & 50.8 \\
Foreign banks & 51 & 8.3 & 9.2 & 108 & 16.9 & 17.6 \\
Large private banks & 183 & 41.2 & 42.8 & 132 & 27.5 & 24.9 \\
Other private banks & 939 & 9.3 & 14 & 656 & 5.0 & 6.5 \\
Other credit institutions & 48 & 0.5 & 0.2 & 56 & 0.4 & 0.2 \\
Total & $\mathbf{1 2 5 3}$ & $\mathbf{1 0 0}$ & $\mathbf{1 0 0}$ & $\mathbf{9 7 8}$ & $\mathbf{1 0 0}$ & $\mathbf{1 0 0}$ \\
\hline
\end{tabular}

* minimum required ratio is $10.0 \%$

** numbers according to the CBR's classification of state ownership - direct holding of more than 50\% 
Table 2. Summary statistics.

The sample includes observations on 348 individual banks over the 2005-2011 fiscal years. Assets growth is calculated as the percentage of current year's total assets to total assets at time $t$ - 1 . Return on average assets is net income divided by book assets. Cost to income is measured by the ratio of operating costs to operating income. State (foreign) share is a percentage of equity stake directly or indirectly held by the government (foreigners). Listed is a dummy variable that takes value of 1 if a bank was listed on a stock exchange during the sample period. H-quarters is a dummy variable for having headquarters in the capital city.

\begin{tabular}{|c|c|c|c|c|c|c|}
\hline Variable & $\begin{array}{l}\text { No. of } \\
\text { Obs. }\end{array}$ & Mean & Median & $\begin{array}{c}\text { Standard } \\
\text { Deviation }\end{array}$ & Min & Max \\
\hline \multicolumn{7}{|l|}{ Asset structure } \\
\hline Total assets (mill. USD) & 2196 & 2496 & 276.8 & 153.3 & 2.12 & 336534 \\
\hline Loans growth & 1829 & 35.07 & 17.54 & 122.0 & 0.66 & 285.5 \\
\hline Assets growth & 2007 & 29.82 & 23.05 & 38.24 & -49.92 & 231.7 \\
\hline Loans loss reserves/Gross loans & 2148 & 8.21 & 5.83 & 8.57 & 0.00 & 108.9 \\
\hline \multicolumn{7}{|l|}{ Capital structure } \\
\hline Equity/Assets & 2152 & 15.85 & 12.84 & 9.93 & 4.78 & 72.92 \\
\hline Equity/Net loans & 2140 & 33.81 & 22.58 & 40.03 & 8.02 & 423.9 \\
\hline Deposits/Assets & 2147 & 56.39 & 57.62 & 18.74 & 5.58 & 88.93 \\
\hline \multicolumn{7}{|l|}{ Income structure } \\
\hline Return on average assets & 2152 & 1.44 & 1.20 & 1.56 & -6.59 & 8.51 \\
\hline Profit before taxes/Assets & 2152 & 1.96 & 1.68 & 1.74 & -6.95 & 11.33 \\
\hline Net interest revenue/Average assets & 2152 & 5.19 & 4.97 & 2.03 & 0.86 & 13.98 \\
\hline Cost to income ratio & 2145 & 75.70 & 80.63 & 20.96 & 24.37 & 121.7 \\
\hline \multicolumn{7}{|l|}{ Ownership structure } \\
\hline State share & 2196 & 4.50 & 0.00 & 18.14 & 0.00 & 100.0 \\
\hline Foreign share & 2196 & 10.0 & 0.00 & 28.77 & 0.00 & 100.0 \\
\hline Listed & 2196 & 0.16 & 0.00 & 0.37 & 0.00 & 1.00 \\
\hline H-quarters & 2196 & 0.56 & 1.00 & 0.49 & 0.00 & 1.00 \\
\hline
\end{tabular}


Table 3. Univariate tests.

The table reports comparisons of means and medians of lending behavior and bank capitalization variables across different ownership types. Panel A presents comparisons for the full sample period, while Panel B compares the crisis period year by year. Loans growth is the percentage growth of total loans over the previous year. Capital ratio is measured by equity to total assets ratio. Average interest on loans is measured as interest income on loans divided by average gross loans. The difference in means (medians) is tested with t-test (Wilcoxon/Mann-Whitney). ${ }^{* * *}, * *$, and $*$ denotes significance at the $1 \%, 5 \%$, and $10 \%$ levels, respectively.

\begin{tabular}{|c|c|c|c|c|c|}
\hline \multicolumn{5}{|c|}{ Panel A. Full sample period 2005-2011 } & \\
\hline & & \multicolumn{2}{|l|}{ State } & rivate & \\
\hline \multicolumn{2}{|l|}{ Loans growth } & \multirow{2}{*}{\multicolumn{2}{|c|}{$35.00 \%$}} & Private & \\
\hline \multicolumn{2}{|l|}{ Mean } & & & $34.92 \%$ & \\
\hline \multicolumn{2}{|l|}{ Median } & \multicolumn{2}{|c|}{$21.17 \%$} & $17.32 \%$ & \\
\hline \multicolumn{2}{|l|}{ No. of obs. } & \multicolumn{2}{|c|}{130} & 1701 & \\
\hline \multicolumn{6}{|l|}{ Capital ratio } \\
\hline \multicolumn{2}{|l|}{ Mean } & \multicolumn{2}{|c|}{$15.61 \%$} & $15.87 \%$ & \\
\hline \multicolumn{2}{|l|}{ Median } & \multicolumn{2}{|c|}{$12.21 \%$} & $12.92 \%$ & \\
\hline \multirow{2}{*}{\multicolumn{2}{|c|}{ Average interest rate on loans }} & \multicolumn{2}{|c|}{147} & 2005 & \\
\hline & & \multirow{2}{*}{\multicolumn{2}{|c|}{$12.98 \% * * *$}} & & \\
\hline \multicolumn{2}{|c|}{ Mean } & & & $.32 \%$ & \\
\hline Median & & \multicolumn{2}{|c|}{$12.92 \% * * *$} & $4.13 \%$ & \\
\hline No. of obs. & & \multicolumn{2}{|c|}{144} & 1759 & \\
\hline & & & & & \\
\hline & 2008 & & 2009 & & 010 \\
\hline State & Private & State & Private & State & Private \\
\hline $7.94 \%$ & $-1.04 \%$ & $11.57 \% * *$ & $-4.92 \%$ & $11.18 \%$ & $24.34 \%$ \\
\hline $7.29 \% *$ & $-4.53 \%$ & $-3.07 \%$ & $-6.38 \%$ & $12.00 \%$ & $16.27 \%$ \\
\hline 20 & 314 & 22 & 290 & 25 & 287 \\
\hline $13.19 \%$ & $16.35 \%$ & $18.61 \%$ & $17.02 \%$ & $18.43 \%$ & $15.76 \%$ \\
\hline $10.94 \%$ & $13.65 \%$ & $14.17 \%$ & $14.18 \%$ & $12.80 \%$ & $12.79 \%$ \\
\hline 19 & 310 & 22 & 291 & 24 & 285 \\
\hline e on loans & & & & & \\
\hline $13.41 \% * *$ & $15.08 \%$ & $14.10 \% * *$ & $15.59 \%$ & $12.08 \% * * *$ & $14.19 \%$ \\
\hline $13.16 \%$ ** & $14.71 \%$ & $13.96 \% * * *$ & $15.51 \%$ & $11.55 \% * * *$ & $13.18 \%$ \\
\hline 20 & 294 & 22 & 279 & 25 & 276 \\
\hline
\end{tabular}


Table 4. State ownership and growth of total loans.

The table reports the estimates of Equation (1) based on an unbalanced panel on 348 banks. The dependent variable in all specifications is Loans Growth rate - the difference between log-loans at time $t$ and log-loans at time $t-1$. Columns 1-3 examine whole sample period 2005-2011, while Columns 4-5 focus specifically on the crisis period 2008-2010. GOV is the percentage of equity stake directly or indirectly held by the government and $\mathrm{GOV}^{2}$ is the squared term of the state ownership variable. $G O V$ High contains ownership stakes for banks where the government held at least $95 \%$ of equity. Column 1 includes Listed and H-quarters - dummy variables for a bank being listed on a stock exchange during the sample period and having headquarters in the capital city, respectively. In Columns 2-5, bank fixed effects are included. Specification in Column 3 includes a dummy variable for the crisis period - Crisis that takes value of 1 in fiscal years of 2008,2009, and 2010, as well as the interaction of the crisis dummy with state and squared state ownership - Crisis $\times G O V$ and Crisis $\times G O V^{2}$. Absolute values of t-statistics are in brackets. All specifications contain heteroskedasticity consistent standard errors and corrected for within-bank error clustering. $* * *, * *$, and * indicate significance at the $1 \%, 5 \%$, and $10 \%$ levels, respectively.

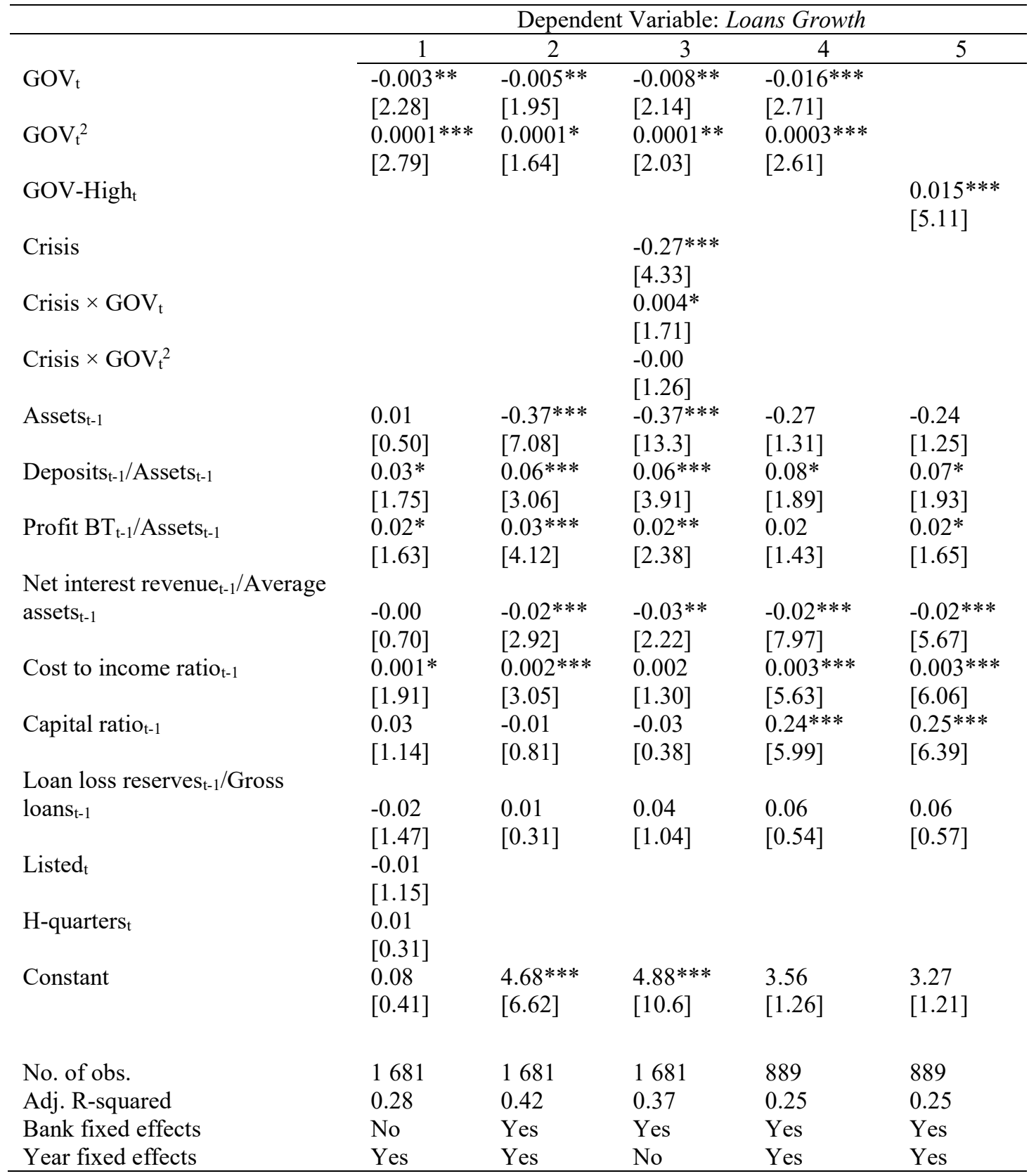


Table 5. State ownership and interest rates on loans.

The table reports the estimates of Equation (2). The dependent variable in all columns - Average interest rate on loans - interest income on loans divided by average gross loans. Columns 1-3 examine whole sample period 2005-2011, while Columns 4-5 focus specifically on the crisis period 2008-2010. $G O V$ is the percentage of equity stake directly or indirectly held by the government and $G O V^{2}$ is the squared term of this variable. GOV-High contains ownership stakes for banks where the government held at least $95 \%$ of equity. Column 1 includes Listed and H-quarters - dummy variables for a bank being listed on a stock exchange during the sample period and having headquarters in the capital city, respectively. In Columns 2-5, bank fixed effects are included. Specification in Column 3 includes a dummy variable for crisis period Crisis that takes value of 1 in fiscal years of 2008, 2009, and 2010, as well as the interaction of the crisis dummy with state ownership and its squared term. Absolute values of t-stats are in brackets. All specifications contain heteroskedasticity consistent standard errors and corrected for within-bank error clustering. ***,**, and * indicate significance at the $1 \%, 5 \%$, and $10 \%$ levels, respectively.

\begin{tabular}{|c|c|c|c|c|c|}
\hline & \multicolumn{5}{|c|}{ Dependent Variable: Average interest rate on loans } \\
\hline & 1 & 2 & 3 & 4 & 5 \\
\hline \multirow[t]{2}{*}{$\mathrm{GOV}_{\mathrm{t}}$} & $-0.07 * * *$ & 0.01 & 0.00 & 0.02 & \\
\hline & {$[6.82]$} & {$[0.13]$} & {$[0.03]$} & [1.63] & \\
\hline \multirow[t]{2}{*}{$\mathrm{GOV}_{\mathrm{t}}^{2}$} & $0.001 * * *$ & -0.00 & -0.00 & $-0.001 * * *$ & \\
\hline & {$[6.65]$} & {$[0.49]$} & {$[0.41]$} & {$[4.79]$} & \\
\hline GOV-Hight $_{t}$ & & & & & $\begin{array}{l}-0.06 * * * \\
{[15.2]}\end{array}$ \\
\hline \multirow[t]{2}{*}{ Crisis } & & & $1.33 * * *$ & & \\
\hline & & & [4.09] & & \\
\hline \multirow[t]{2}{*}{ Crisis $\times \mathrm{GOV}_{\mathrm{t}}$} & & & $-0.01 *$ & & \\
\hline & & & {$[1.75]$} & & \\
\hline \multirow{2}{*}{ Crisis $\times \mathrm{GOV}_{\mathrm{t}}^{2}$} & & & 0.00 & & \\
\hline & & & {$[0.85]$} & & \\
\hline \multirow[t]{2}{*}{ Assets $_{t}$} & $-0.11 * *$ & 0.06 & -0.25 & 0.39 & 0.33 \\
\hline & [1.99] & {$[0.17]$} & {$[1.54]$} & {$[0.57]$} & {$[0.47]$} \\
\hline \multirow[t]{2}{*}{ Deposits $_{t} /$ Assets $_{t}$} & 0.19 & -0.03 & 0.10 & -0.26 & -0.27 \\
\hline & {$[1.38]$} & {$[0.14]$} & {$[0.40]$} & {$[0.71]$} & {$[0.81]$} \\
\hline \multirow{2}{*}{ Profit BT $_{t} /$ Assets $_{t}$} & 0.10 & $0.19 * *$ & 0.14 & 0.06 & 0.04 \\
\hline & {$[1.32]$} & {$[2.07]$} & {$[1.46]$} & {$[0.98]$} & {$[0.60]$} \\
\hline \multirow{3}{*}{$\begin{array}{l}\text { Net interest revenue } / \text { /Average } \\
\text { assets }_{t}\end{array}$} & & & & & \\
\hline & $0.66 * * *$ & $0.72 * * *$ & $0.71 * * *$ & $0.75 * * *$ & $0.76 * * *$ \\
\hline & {$[8.41]$} & {$[15.6]$} & {$[30.2]$} & {$[14.5]$} & {$[15.1]$} \\
\hline \multirow[t]{2}{*}{ Cost to income ratio $t$} & 0.01 & -0.00 & $-0.01 * *$ & -0.01 & -0.01 \\
\hline & {$[1.10]$} & {$[0.02]$} & {$[2.01]$} & {$[0.74]$} & {$[0.97]$} \\
\hline \multirow[t]{2}{*}{ Capital ratio $_{t}$} & $-1.16^{* * *}$ & $-1.45 * * *$ & $-1.35 * * *$ & -0.73 & -0.73 \\
\hline & {$[3.66]$} & {$[3.96]$} & {$[3.03]$} & {$[1.15]$} & {$[1.13]$} \\
\hline \multirow[t]{2}{*}{ Loan loss reserves $/$ Gross loans $s_{t}$} & 0.09 & $0.30 *$ & $0.35^{*}$ & $0.66^{* * *}$ & $0.61 * * *$ \\
\hline & {$[1.16]$} & {$[1.85]$} & {$[1.77]$} & {$[9.47]$} & {$[8.14]$} \\
\hline \multirow[t]{2}{*}{ Growth $_{\mathrm{t}}$} & 0.00 & -0.00 & -0.00 & -0.00 & -0.00 \\
\hline & {$[0.44]$} & {$[0.74]$} & {$[0.63]$} & {$[0.99]$} & {$[0.92]$} \\
\hline \multirow[t]{2}{*}{ Average rate on deposits ${ }_{t}$} & $0.01 *$ & $0.01 *$ & $0.01 *$ & $0.03 * * *$ & $0.03 * * *$ \\
\hline & {$[1.72]$} & [1.91] & [1.89] & {$[3.07]$} & {$[2.96]$} \\
\hline \multirow[t]{2}{*}{ Listed $_{t}$} & 0.19 & & & & \\
\hline & {$[1.16]$} & & & & \\
\hline \multirow[t]{2}{*}{$\mathrm{H}$-quarters $\mathrm{t}_{\mathrm{t}}$} & $-1.42 * * *$ & & & & \\
\hline & {$[5.76]$} & & & & \\
\hline \multirow[t]{2}{*}{ Constant } & $9.40 * * *$ & 5.86 & $9.81 * * *$ & 2.99 & 4.12 \\
\hline & {$[8.50]$} & {$[1.36]$} & {$[5.14]$} & {$[0.36]$} & {$[0.49]$} \\
\hline No. of obs. & 1587 & 1587 & 1587 & 751 & 751 \\
\hline Adj. R-squared & 0.29 & 0.64 & 0.62 & 0.70 & 0.71 \\
\hline Bank fixed effects & No & Yes & Yes & Yes & Yes \\
\hline Year fixed effects & Yes & Yes & No & Yes & Yes \\
\hline
\end{tabular}


Table 6. State ownership and bank capitalization.

The table reports the estimates of Equation (3). The dependent variable in all columns is logarithm of capital ratio measured by total equity divided by total assets. Columns 1-3 examine whole sample period 2005-2011, while Columns 4-5 focus specifically on the crisis period 2008-2010. GOV is the percentage of equity stake directly or indirectly held by the government and $G O V^{2}$ is the squared term of this variable. $G O V_{\text {Dum }}$ is a dummy variable that takes value of 1 if government held more than $20 \%$ of bank's equity. Column 1 includes Listed and H-quarters - dummy variables for a bank being listed on a stock exchange during the sample period and having headquarters in the capital city, respectively. In Columns 2-5, bank fixed effects are included. Specification in Column 3 includes a dummy variable for crisis period Crisis that takes value of 1 in fiscal years of 2008, 2009, and 2010, as well as the interaction of the crisis dummy with state ownership and its squared term. Absolute values of t-stats are in brackets. All specifications contain heteroskedasticity consistent standard errors and corrected for within-bank error clustering. $* * *, * *$, and $*$ indicate significance at the $1 \%, 5 \%$, and $10 \%$ levels, respectively.

\begin{tabular}{|c|c|c|c|c|c|}
\hline & \multicolumn{5}{|c|}{ Dependent Variable: Capital ratio } \\
\hline & 1 & 2 & 3 & 4 & 5 \\
\hline \multirow[t]{2}{*}{$\mathrm{GOV}_{\mathrm{t}}$} & 0.00 & 0.00 & 0.00 & 0.01 & \\
\hline & {$[0.64]$} & {$[0.71]$} & {$[0.85]$} & {$[1.57]$} & \\
\hline \multirow[t]{2}{*}{$\mathrm{GOV}_{\mathrm{t}}^{2}$} & $0.00 *$ & 0.00 & 0.00 & 0.00 & \\
\hline & {$[1.67]$} & {$[0.91]$} & {$[1.14]$} & {$[1.40]$} & \\
\hline \multirow[t]{2}{*}{$\mathrm{GOV}_{\text {Dum }}$} & & & & & $0.18 * *$ \\
\hline & & & & & {$[2.32]$} \\
\hline \multirow[t]{2}{*}{ Crisis } & & & $0.08 * * *$ & & \\
\hline & & & {$[4.13]$} & & \\
\hline \multirow[t]{2}{*}{ Crisis $\times \mathrm{GOV}_{\mathrm{t}}$} & & & 0.00 & & \\
\hline & & & {$[0.38]$} & & \\
\hline \multirow[t]{2}{*}{ Crisis $\times \mathrm{GOV}_{\mathrm{t}}^{2}$} & & & 0.00 & & \\
\hline & & & {$[0.84]$} & & \\
\hline \multirow[t]{2}{*}{ Assets $_{\mathrm{t}-1}$} & $-0.06 * * *$ & $-0.08 * *$ & $-0.08 * * *$ & 0.02 & 0.02 \\
\hline & {$[7.97]$} & {$[2.38]$} & {$[4.67]$} & {$[0.28]$} & {$[0.23]$} \\
\hline \multirow[t]{2}{*}{ Deposits $_{\mathrm{t}-1} /$ Assets $_{\mathrm{t}-1}$} & $-0.12 * * *$ & -0.02 & -0.02 & $0.04 * *$ & $0.04 * * *$ \\
\hline & {$[8.38]$} & [1.19] & {$[0.65]$} & {$[2.27]$} & {$[3.21]$} \\
\hline \multirow[t]{2}{*}{ Profit $\mathrm{BT}_{\mathrm{t}-1} /$ Assets $_{\mathrm{t}-1}$} & $0.06 * * *$ & 0.00 & $0.01 * *$ & 0.00 & 0.00 \\
\hline & {$[7.36]$} & {$[0.88]$} & [1.97] & {$[0.36]$} & {$[0.32]$} \\
\hline \multicolumn{6}{|l|}{ Net interest revenue $t_{-1} /$ Average } \\
\hline \multirow[t]{2}{*}{$\operatorname{assets}_{\mathrm{t}-1}$} & $0.02 * * *$ & 0.00 & 0.00 & 0.00 & 0.00 \\
\hline & {$[4.17]$} & {$[0.02]$} & {$[0.84]$} & {$[0.61]$} & {$[0.70]$} \\
\hline \multirow[t]{2}{*}{ Cost to income ratio $t-1$} & $-0.002 * * *$ & $-0.001 * *$ & $-0.001 *$ & $-0.001 * *$ & $-0.001 * * *$ \\
\hline & {$[3.92]$} & {$[2.49]$} & {$[1.68]$} & {$[2.48]$} & {$[2.76]$} \\
\hline \multirow[t]{2}{*}{ Loan loss reserves $\mathrm{t}_{\mathrm{t}-1} / \mathrm{Gross}$ loans $_{\mathrm{t}-1}$} & 0.02 & $0.06 * * *$ & $0.03 * * *$ & $0.05 * * *$ & $0.05 * * *$ \\
\hline & {$[1.50]$} & {$[6.29]$} & [2.59] & {$[3.26]$} & {$[3.28]$} \\
\hline \multirow[t]{2}{*}{ Growth $_{\mathrm{t}-1}$} & $-0.002 * * *$ & $-0.001 * * *$ & $-0.001 * * *$ & -0.00 & -0.00 \\
\hline & {$[5.63]$} & {$[2.85]$} & {$[3.88]$} & [0.99] & {$[0.95]$} \\
\hline \multirow[t]{2}{*}{ Listed $_{t}$} & $-0.02 *$ & & & & \\
\hline & {$[1.91]$} & & & & \\
\hline \multirow[t]{2}{*}{$\mathrm{H}$-quarters $\mathrm{t}_{\mathrm{t}}$} & $0.17 * * *$ & & & & \\
\hline & {$[6.10]$} & & & & \\
\hline \multirow[t]{2}{*}{ Constant } & $-1.40 * * *$ & $-0.94 * *$ & $-0.94 * * *$ & $-2.25 * *$ & $-2.21 * *$ \\
\hline & {$[40.4]$} & {$[2.08]$} & {$[4.08]$} & {$[2.24]$} & {$[2.21]$} \\
\hline No. of obs. & 1514 & 1514 & 1514 & 842 & 842 \\
\hline Adj. R-squared & 0.23 & 0.77 & 0.76 & 0.83 & 0.83 \\
\hline Bank fixed effects & No & Yes & Yes & Yes & Yes \\
\hline Year fixed effects & Yes & Yes & No & Yes & Yes \\
\hline
\end{tabular}


Table 7. The effects of state intervention on bank lending behavior and capitalization

The table reports the estimates of Equations (1-3) for the sub-sample period of 2008-2011. The dependent variable in Column 1 is the difference between log-loans at time $t$ and log-loans at time $t$ - 1 , in Column 2 - average interest rate on loans - interest income on loans divided by average gross loans, and in Column 3 - logarithm of capital ratio measured by total equity divided by total assets. GOV-SUP is a dummy variable that takes the value of 1 if bank received monetary support from the government. Control variables in Columns 1 and 3 are lagged by one year. Absolute values of t-stats are in brackets. Standard errors are corrected for heteroskedasticity and within-bank error clustering. Year fixed effects are included in all specifications. $* * *, * *$, and * indicate significance at the $1 \%, 5 \%$, and $10 \%$ levels, respectively.

\begin{tabular}{|c|c|c|c|}
\hline & \multicolumn{3}{|c|}{ Dependent Variables } \\
\hline & Loans growth & $\begin{array}{l}\text { Average interest } \\
\text { rate on loans }\end{array}$ & Capital ratio \\
\hline & 1 & 2 & 3 \\
\hline \multirow[t]{2}{*}{ GOV-SUP } & $0.13^{* * *}$ & $-1.42 * * *$ & $-0.07 *$ \\
\hline & {$[6.40]$} & {$[8.70]$} & {$[1.78]$} \\
\hline \multirow[t]{2}{*}{ Assets } & 0.01 & $-0.31 * * *$ & $-0.05 * * *$ \\
\hline & {$[1.34]$} & {$[9.23]$} & {$[5.02]$} \\
\hline \multirow[t]{2}{*}{ Deposits/Assets } & $0.04 *$ & -0.02 & $-0.09 * * *$ \\
\hline & {$[1.69]$} & {$[0.13]$} & {$[9.77]$} \\
\hline \multirow[t]{2}{*}{ Profit BT/Assets } & $0.03 * * *$ & 0.11 & $0.06 * * *$ \\
\hline & {$[3.07]$} & {$[1.46]$} & {$[4.56]$} \\
\hline \multirow[t]{2}{*}{ Net interest revenue/Average assets } & -0.01 & $0.55 * * *$ & $0.03 * * *$ \\
\hline & {$[0.71]$} & {$[5.64]$} & {$[9.06]$} \\
\hline \multirow[t]{2}{*}{ Cost to income ratio } & $0.002 * * *$ & $-0.02 * * *$ & $-0.002 * *$ \\
\hline & {$[2.57]$} & {$[3.52]$} & {$[2.27]$} \\
\hline \multirow[t]{2}{*}{ Capital ratio } & 0.02 & $-1.48 * * *$ & \\
\hline & {$[0.43]$} & {$[3.38]$} & \\
\hline \multirow[t]{2}{*}{ Loan loss reserves/Gross loans } & -0.01 & $0.18 * *$ & 0.01 \\
\hline & {$[0.88]$} & {$[2.08]$} & {$[0.90]$} \\
\hline \multirow[t]{2}{*}{ Growth } & & 0.00 & $-0.002 * * *$ \\
\hline & & {$[0.26]$} & {$[4.78]$} \\
\hline \multirow[t]{2}{*}{ Average rate on deposits } & & $0.01 * *$ & \\
\hline & & {$[2.48]$} & \\
\hline \multirow[t]{2}{*}{ Constant } & $-0.27 * * *$ & $13.9 * * *$ & $-1.41 * * *$ \\
\hline & {$[2.65]$} & {$[12.4]$} & {$[8.62]$} \\
\hline No. of obs. & 1163 & 989 & 1113 \\
\hline Adj. R-squared & 0.12 & 0.22 & 0.20 \\
\hline Bank fixed effects & No & No & No \\
\hline Year fixed effects & Yes & Yes & Yes \\
\hline
\end{tabular}


Figure 1. Loan growth and state ownership of banks

(A)

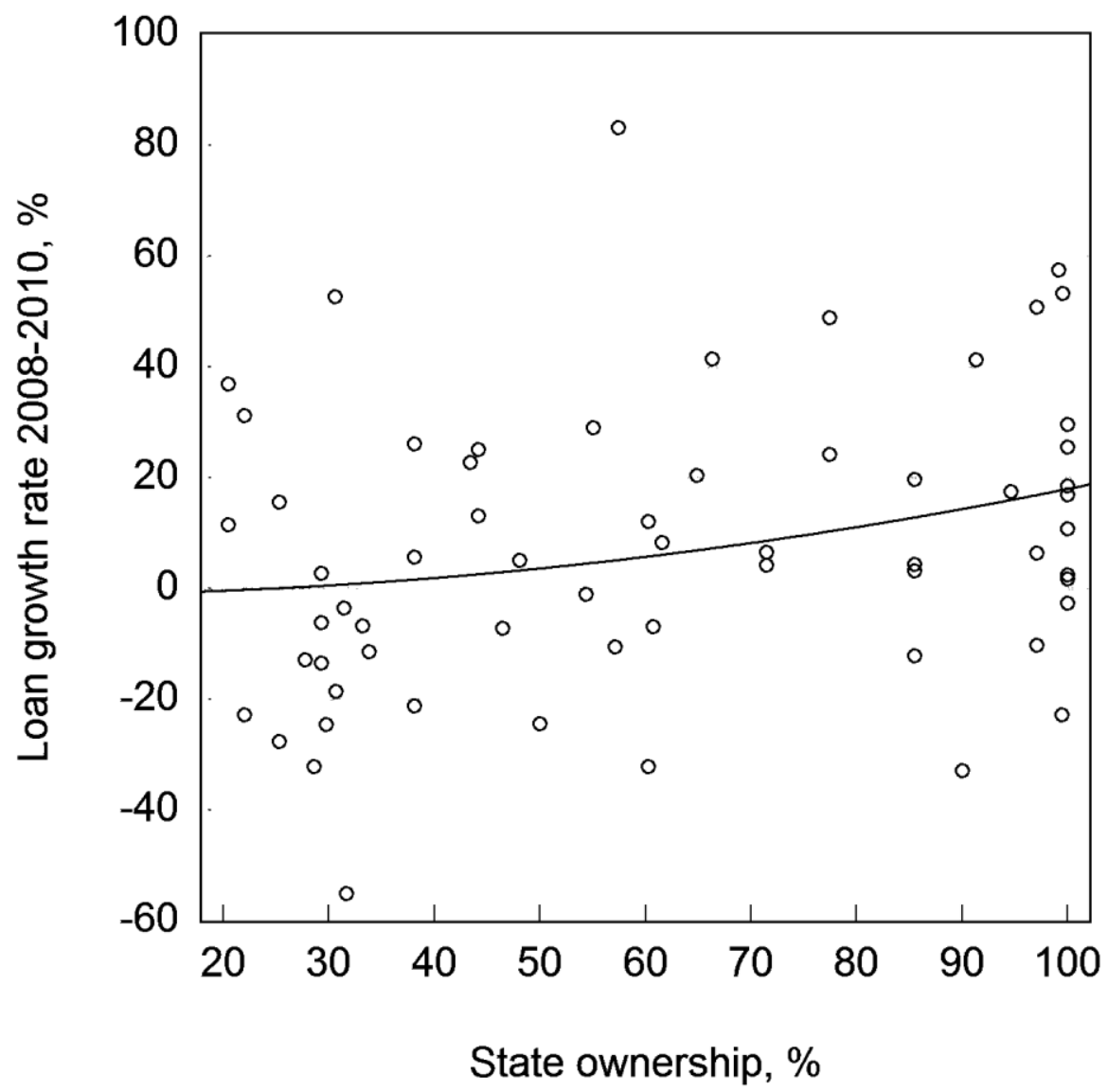

(B)

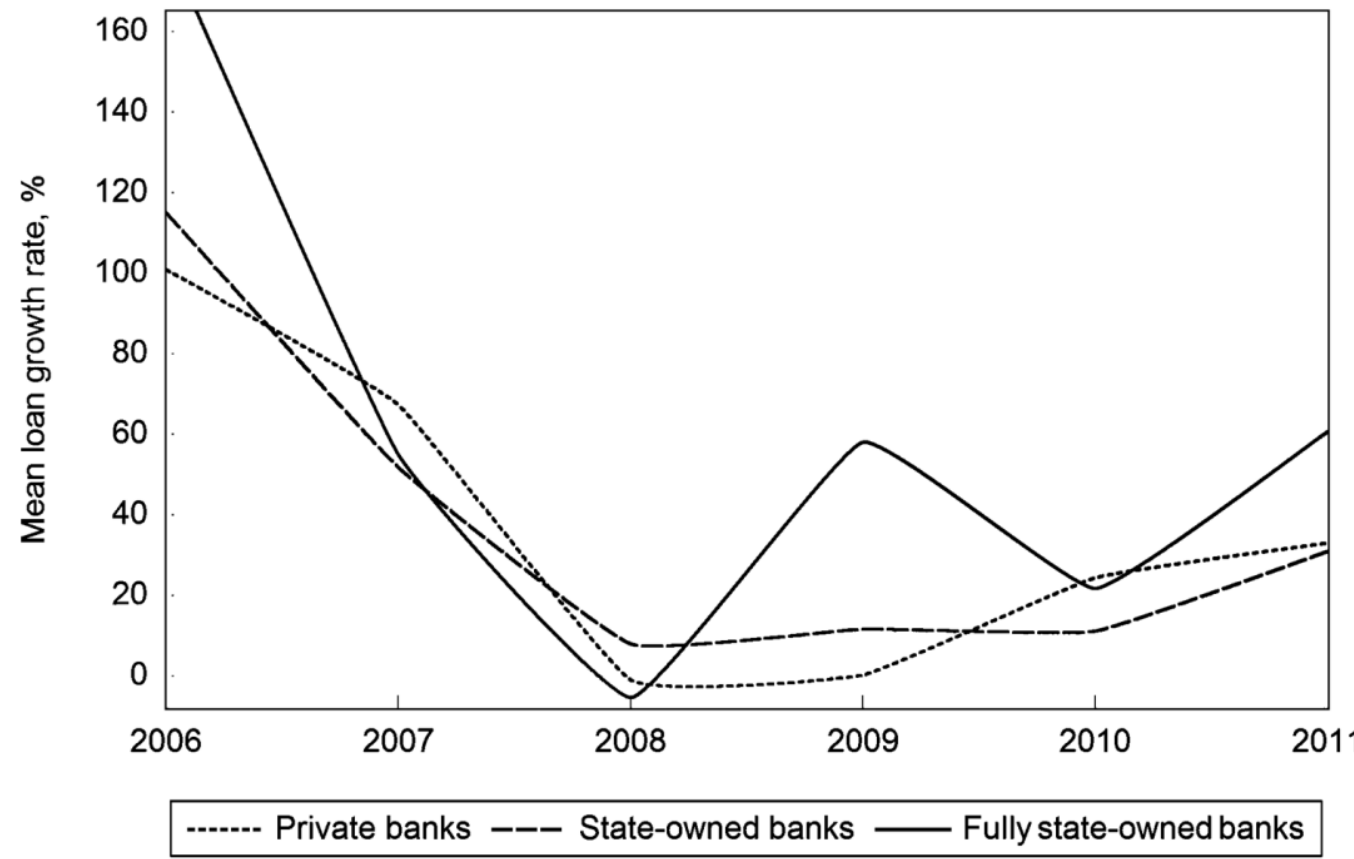


Figure 2. Interest rates on loans and state ownership of banks

(A)

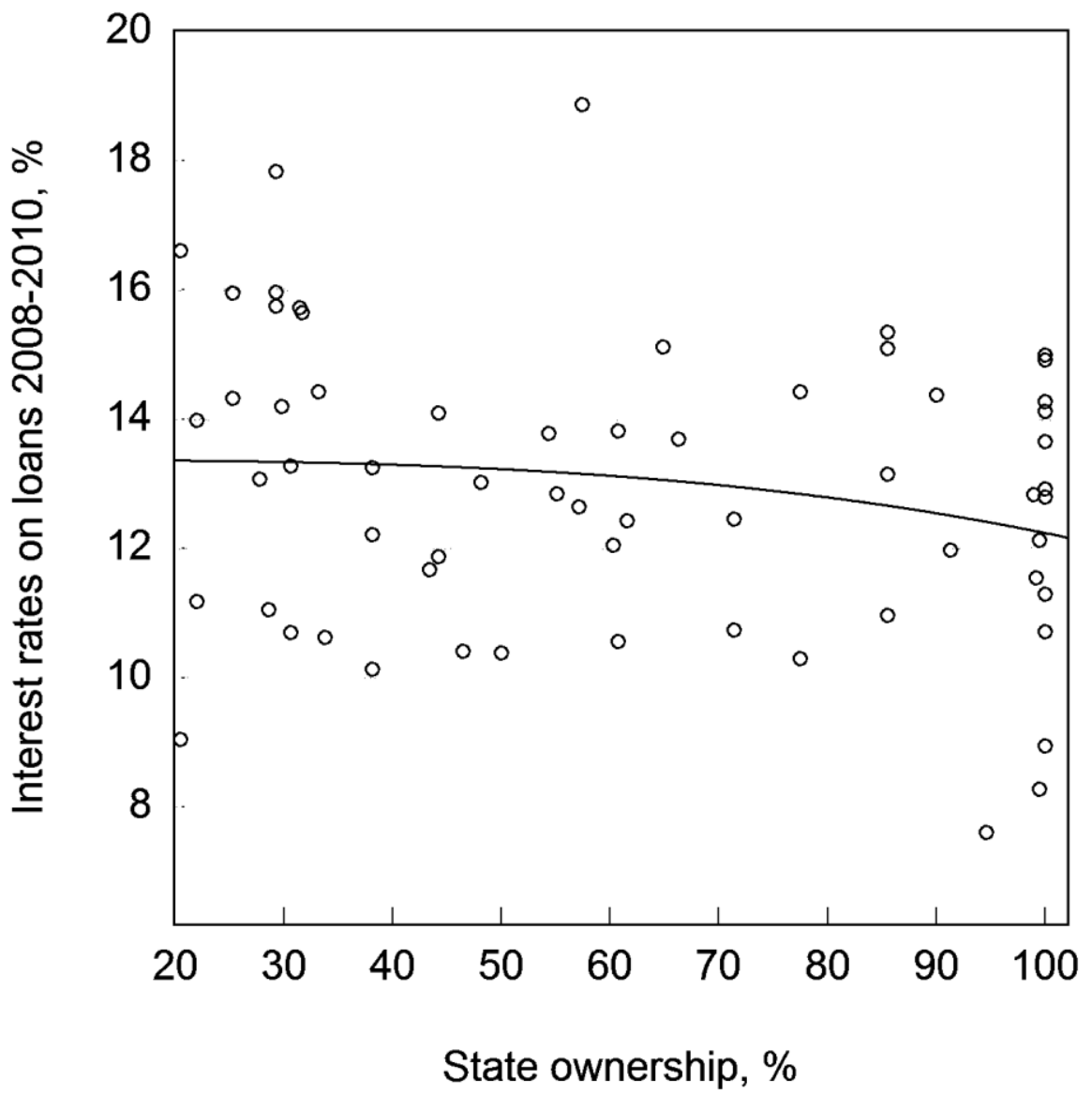

(B)

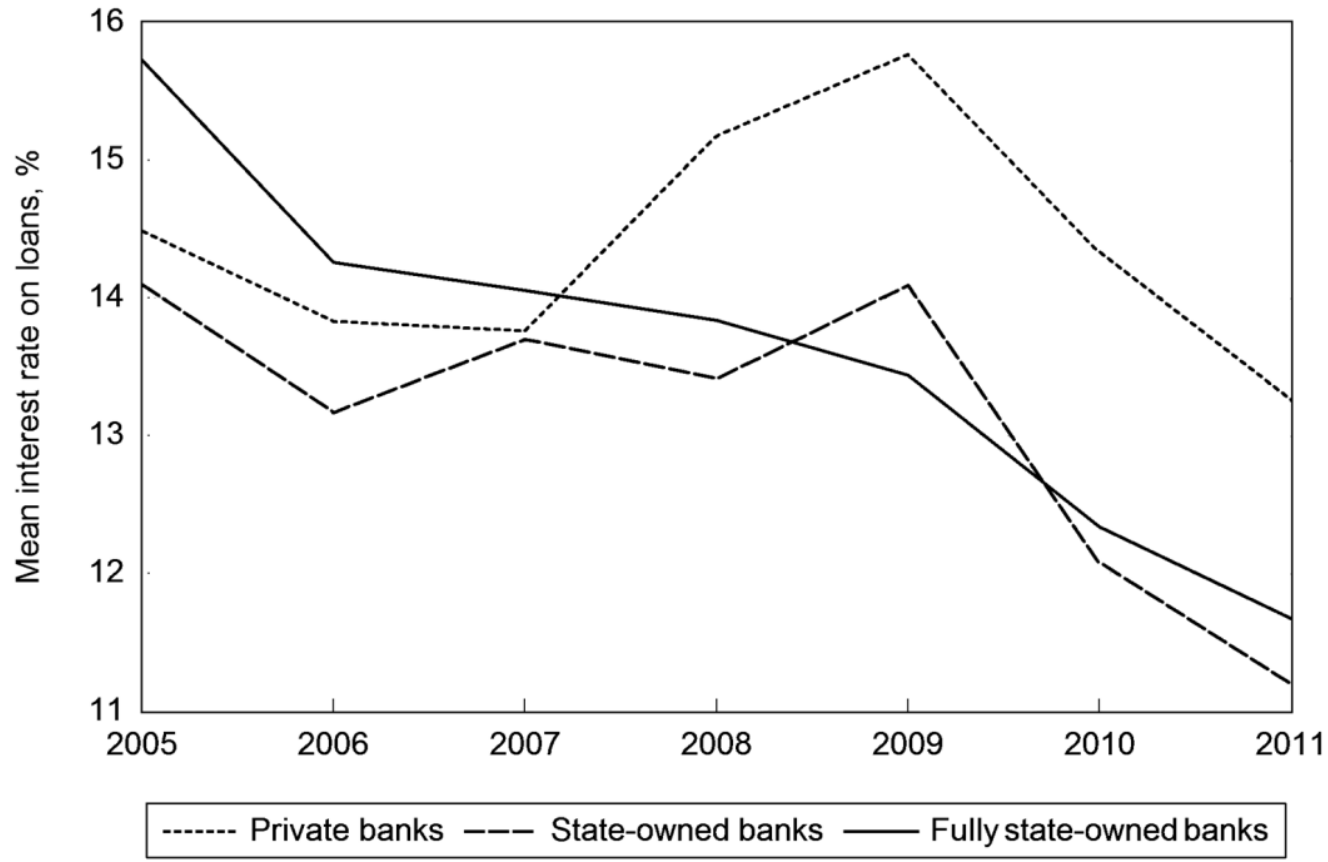

